\title{
Phylogenetic Relationships of Twenty-One Nereids Species Inferring Two Different Evolutionary Origins?
}

\author{
Ming Liu \\ Dept. of Ecology and Environment, Mariculture Institute of Shandong Province \\ Rd. 47 Guizhou, Qingdao 266002, China \\ Tel: 86-532-8265-5167 E-mail: shelleyliuming@hotmail.com \\ Hongjun Liu (Corresponding author) \\ Dept. of Ecology and Environment, Mariculture Institute of Shandong Province \\ Rd. 47 Guizhou, Qingdao 266002, China \\ Tel: 86-532-8268-1569_E-mail: hongjunl@126.com
}

Qixiang Wang

Dept. of Ecology and Environment, Mariculture Institute of Shandong Province

Rd. 47 Guizhou, Qingdao 266002, China

Tel: 86-532-8265-5167_E-mail: wqxbx@163.com

Shuguang Guan

Dept. of Ecology and Environment, Mariculture Institute of Shandong Province

Rd. 47 Guizhou, Qingdao 266002, China

Tel: 86-532-8265-5167_E-mail:wqxbx@163.com

\section{Shanshan Ge}

Dept. of Marine Life Science, Ocean university of China

Rd. 5 Yushan, Qingdao 266003, China

Tel: 86-532-8265-5167Ｅ-mail: shanshang@126.com 


\section{Macrothink Institute ${ }^{\mathrm{TM}}$}

Received: August 28, 2012

doi:10.5296/ast.v1i1.2980
Aquatic Science and Technology

ISSN 2168-9148 2013, Vol. 1, No. 1

Accepted: September 27, 2012

Published: January 1, 2013

URL: http://dx.doi.org/10.5296/ast.v1i1.2980

\begin{abstract}
Fragments of mitochondrial cytochrome c oxidase subunit I (COI) gene of 21 nereids species were collected and compared to investigate the systematic and evolution of Nereididae. Total of 599 base pair (bp) nucleotide sequences revealed 285 polymorphic sites. Forty-nine variable sites were found in the corresponding 199 amino acid fragments. Phylogeny was constructed based on neighbor-joining (NJ) and maximum likelihood (ML) methods. Two shallow evolutionary clades were found, which were associated with the main distributions or sampling locations of these species that were used in this study. It likely indicated two different evolutionary origins, a Pacific tropic zone and a North Atlantic high latitude zone.
\end{abstract}

Keywords: Nereididae, COI gene, DNA barcode, Taxonomy, Phylogeny, Evolution 


\section{Introduction}

Nereididae Blainville, 1818, is a family of Polychaeta (Annelida). Most members of this group are widely distributed in global marine systems ranging from the intertidal to abyssal depths (Dean, 2001), while a few also settle down in brackish or swim upstream to rivers even to land. They are commercially and ecologically important, because they can contribute as abundant food sources in the marine communities and improve the quality of benthic sediment as well as monitor pollution (Jiang \& Liu, 2008). Presently, Nereididae are commonly thought to contain 42 genera about 500 species (Pleijel, 2001), but the relationships between them are yet unclear. Traditionally, they were divided into three subfamilies, Gymnonereidinae Banse, 1977a, Namanereidinae Hartman, 1959, and Nereidinae Johnston, 1865. Two controversial subfamilies, Dendronereinae Pillai, 1961 and Notophycinae Knox and Cameron, 1970, are still under incertae sedis (Read \& Fauchald, 2012).

Of all the 42 genera, nineteen with about 81 species are reported to have a distribution or be found along coastal China. Sun and Yang (2004) summarize them into three subfamilies, Nereidinae (16 genera including Dendronereis 77 species), Namanereidinae (2 genera 3 species) and Notophycinae (only one species). The Gymnonereidinae was lack in their records. However, Fitzhugh (1987) suggest expanding the classification limits for Namanereidinae because the Nereidinae were not a monophyletic group based on morphological phylogeny. As his suggestion, five genera divided into Nereidinae by Sun and Yang (2004) can be merged into Gymnonereidinae. Current taxonomy in Nereididae principally depends on morphologic characters such as prostomium, palps, parapodum, jaws and so on. The types and numbers of morphologic characters used and hypotheses on origination, vertical or horizontal evolutions both may generate different taxonomic results. In addition, colour polymorphisms in polychaete species also make confusion in traditional taxonomy (Nygren et al., 2011).

With the rapid development of molecular tools, they have been recognized as necessary for delineating species boundaries, quantifying diversity, and clarifying distributions in understudied groups (Westheide \& Schmidt, 2003; Carr et al., 2011). Mitochondrial DNA (mtDNA) has been applied widely in the studies of phylogenetics and evolution as well as an effective marker to assist taxonomy because of its uniparental inheritance (in a majority of animal phyla), high evolutionary rate, lack of introns, large copy numbers in every cell, and limited recombination (Adriana et al., 2010). Especially, the mitochondrial cytochrome c oxidase subunit I (COI) gene has been proposed as a DNA barcode and frequently used to recognize provisional species in groups with incomplete taxonomy, and morphological, ecological, and behavioural differences are regularly detected upon further examination of divergent taxa (Carr et al., 2011). Although several recent studies have focused on the discrimination of closely related polychaete species (Dahlgren et al., 2000; Santos et al., 2005; Bakken et al., 2005), the systematics and taxon in nereids species by employing molecular data still received few attentions.

In present study, all the available mtDNA COI gene sequences with long fragment in 
Nereididae were collected from Genebank. Our aim is to describe the phylogeny of Nereididae based on COI gene and discuss the possibillity using this marker as a criterion for taxon of Nereididae. A most common nereids species in China, Perinereris aibuhitensis, sampled from coastal Shandong Peninsula of China were brought in to clarify its taxonomic status in Nereididae and investigate the difference of genetic variations between species and within species. Such results can provide theoretical basis for evolution and taxonomy of Nereididae members.

\section{Materials and Methods}

\subsection{Sequences Collection}

COI gene sequences with more than $600 \mathrm{bp}$ length of twenty nereids species were collected from present Genebank. Eighteen of them were from Nereididae and the other two were from Hesionidae and Syllidae respectively to be used as outgroup. Four Perinereris aibuhitensis individuals were brought in from previous population study (Liu et al., 2012). All the samples information was listed in Table 1 and the probable sampling locations were shown in Fig. 1.

Table 1. Samples informations

\begin{tabular}{|c|c|c|c|c|c|c|}
\hline Family & Subfamily & Genus & Species & ID & Genebank & Reference \\
\hline \multirow[t]{22}{*}{ Nereididae } & Namanereidinae & Namalycastis & Namalycastis elobeyensis & 01 & JQ040828 & Magesh, 2012* \\
\hline & & & Namalycastis abiuma ${ }^{@}$ & 02 & JQ081269 & Magesh, 2010* \\
\hline & Nereidinae & Cheilonereis & Cheilonereis cyclurus $^{@}$ & 03 & HM473330 & Carr et al., 2011 \\
\hline & & Hediste & Hediste atoka & 04 & AB603886 & Tosuji and Sato, 2010 \\
\hline & & & Hediste japonica & 05 & AB603758 & Tosuji and Sato, 2010 \\
\hline & & Micronereis & Micronereis nanaimoensis & 06 & HM473464 & Carr et al., 2011 \\
\hline & & Neanthes & Neanthes virens & 07 & AF221572 & Dahlgren et al., 2000 \\
\hline & & Nereis & Nereis heterocirrata ${ }^{@}$ & 08 & GU362684 & Zhou et al., 2010 \\
\hline & & & Nereis pelagica@ & 09 & GU670828 & Hardy et al., 2011 \\
\hline & & & Nereis vexillosa ${ }^{@}$ & 10 & HM473512 & Carr et al., 2011 \\
\hline & & & Nereis zonata@ & 11 & HQ024403 & Carr et al., 2011 \\
\hline & & Perinereis & Perinereis aibuhitensis ${ }^{@}$ & 12 & JX661449 & Liu et al., 2012 \\
\hline & & & Perinereis aibuhitensis $^{@}$ & 12 & JX661450 & Liu et al., 2012 \\
\hline & & & Perinereis aibuhitensis $^{@}$ & 12 & JX661443 & Liu et al., 2012 \\
\hline & & & Perinereis aibuhitensis ${ }^{@}$ & 12 & JX661463 & Liu et al., 2012 \\
\hline & & & Perinereis falklandica & 13 & HQ705185 & Sampertegui et al., 2011* \\
\hline & & & Perinereis gualpensis & 14 & HQ705189 & Sampertegui et al., 2011* \\
\hline & & & Perinereis longidonta & 15 & HQ705191 & Sampertegui et al., 2011* \\
\hline & & & Perinereis singaporiensis & 16 & EU835665 & Neave et al., 2008* \\
\hline & & & Perinereis vallata ${ }^{@}$ & 17 & HQ705195 & Sampertegui et al., 2011* \\
\hline & & Platynereis & Platynereis bicanaliculata ${ }^{@}$ & 18 & HM473598 & Carr et al., 2011 \\
\hline & & & Platynereis dumerilii ${ }^{@}$ & 19 & AF178678 & Boore and Brown, 2000 \\
\hline Hesionidae & Hesioninae & Nereimyra & Nereimyra aphroditoides & 20 & HQ024398 & Carr et al., 2011 \\
\hline Syllidae & Autolytinae & Epigamia & Epigamia alexandri & 21 & HQ024298 & Carr et al., 2011 \\
\hline
\end{tabular}

Note: ${ }^{\circledR}$, distributed in China; *, unpublished data.

\subsection{Data Analyses}

All the sequences were edited and aligned using DNASTAR (DNASTAR Inc; www.dnastar.com). The variable sites, transitions and transversions, base compositions and the genetic distance based on Kimura-2-Parameter between pair sequences were performed in MEGA 5.0 (Tamura et al., 2011). The relations between genetic distance and transition and 
transversion for pairwise sequence comparisons were analyzed by DAMBE (Xia, 2000). The NJ tree (Saitou \& Nei, 1987) and ML tree (Felsenstein, 1981) were both constructed in MEGA with 10,000 bootstrap replicates (Felsenstein, 1985).

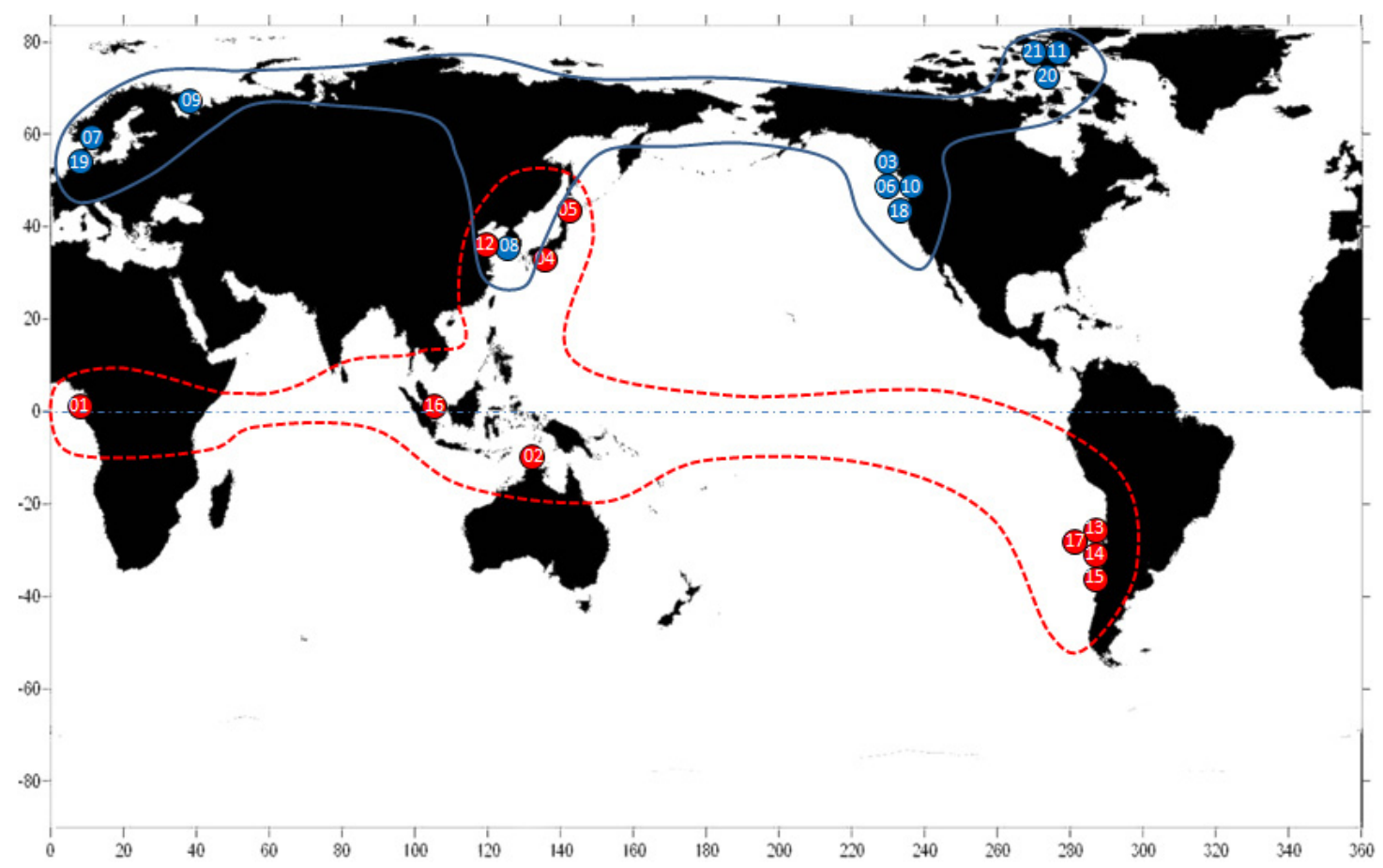

Figure 1. Sampling locations of species used in this study

Note: The numbers correspond to the specific name given in Table 1. Red color represents the species belong to clade A, and blue color represents the ones belong to clade B.

\section{Results}

\subsection{Sequence Variations}

After all sequences were aligned and disposed, total of $599 \mathrm{bp}$ fragment were left for further analyses. Nucleotide comparison of the segment revealed 285 polymorphic sites, of which 246 were parsimony. All pair sequence comparisons produced avg. 65 transitions ( $s i$ ) and 64 transversions $(s v)$. The ratio of $\mathrm{si} / \mathrm{sv}$ is 1.07 . The average base content for $\mathrm{A}+\mathrm{T}$ is $57.5 \%$ versus $42.5 \%$ for $\mathrm{C}+\mathrm{G}$. As a protein-coding gene, nucleotide comparisons for three coden positions were also shown in Table 2 respectively. The AT content for the third coding position is much richer than the other two positions (Table 2). The avg. si/sv ratio is quite high for the first coding position (3.37), but they were below 1.0 for both the second and the third position ( 0.70 and 0.82 respective).

The pairwise distances between 21 species ranged from 0.029 (Namalycastis abiuma vs. Namalycastis elobeyensis) to 0.349 (Nereis heterocirrata vs. Nereimyra aphroditoides). Comparing with interspecific difference, intraspecific variations for $P$. aibuhitensis were small, ranging only from 0.005 to 0.014 (Fig. 2). When the pairwise distances were low, the transitions were higher than transversions. However, as the genetic distances increase, transitions start to saturate but transversions keep on growing (Fig. 3). 


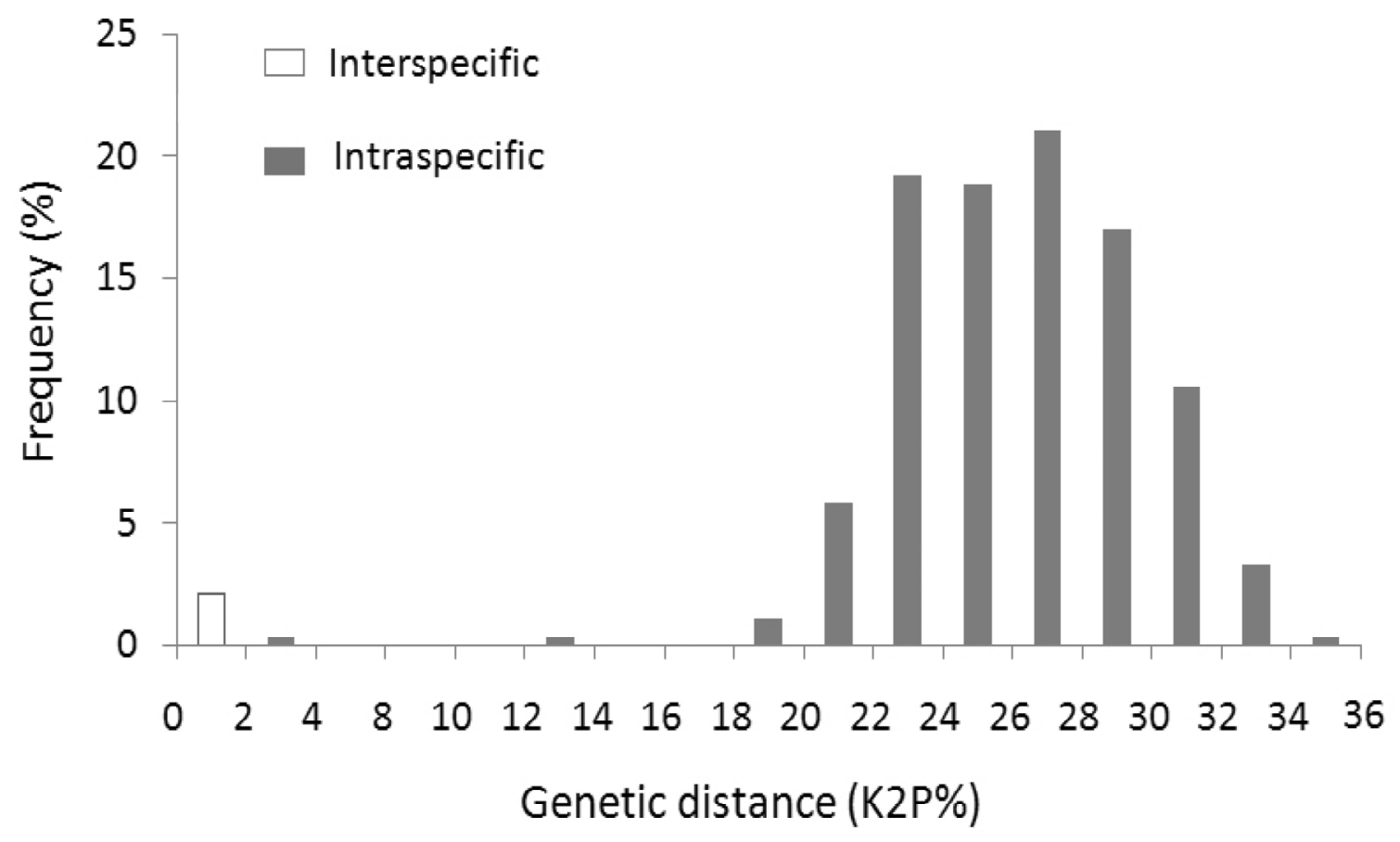

Figure 2. Frequency distribution of COI (K2P) distances within Perinereis aibuhitensis and between species

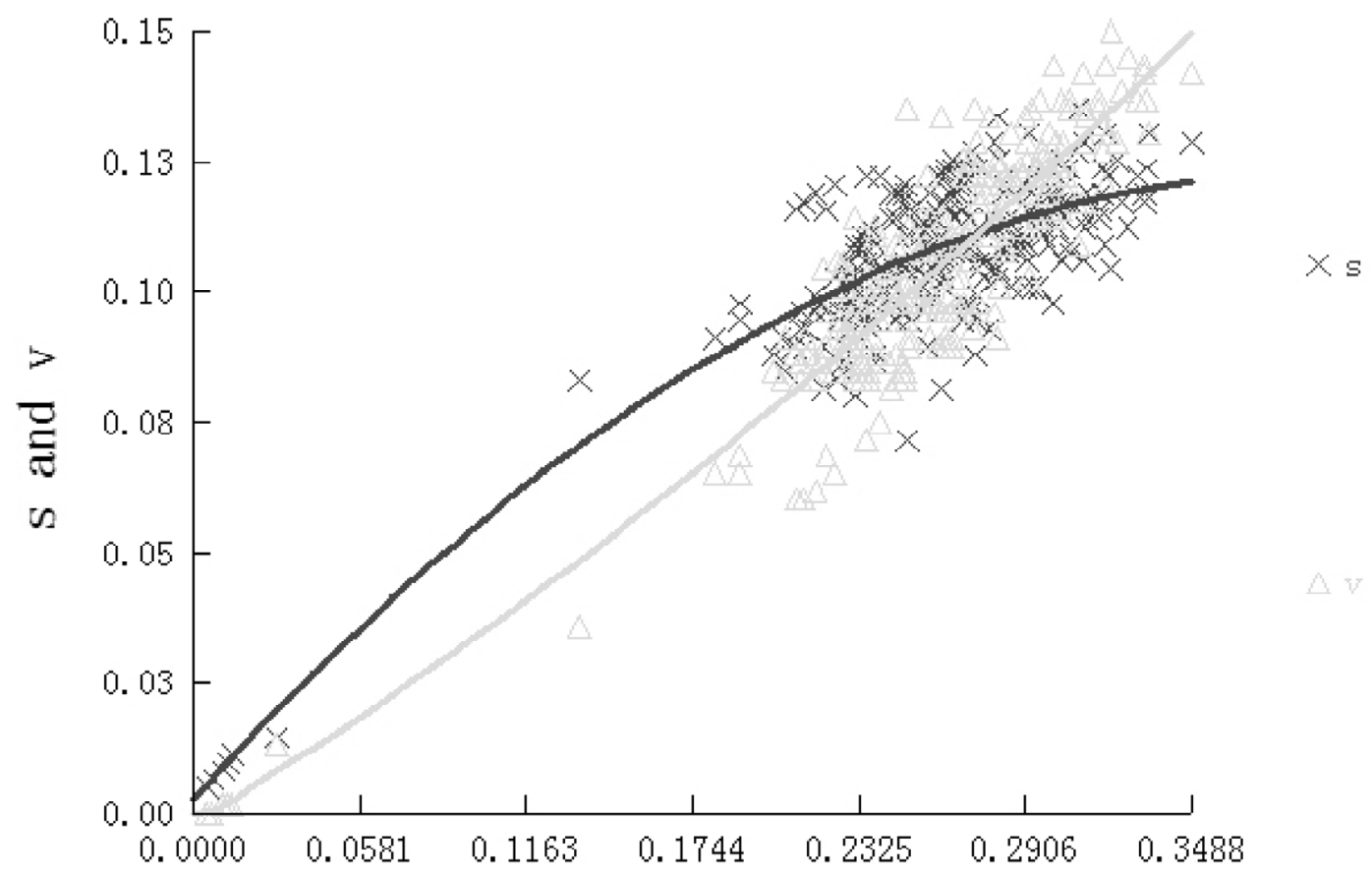

Figure 3. The relationship of the genetic distance vs. the numbers of transition and transversion 
All the 599 bp nucleotides coded total 199 amino acids, which defined 49 variable sites including 21 parsimony informative sites. The information of variable sites for each species was listed in Table 3.

Table 2. Basic statistics of COI gene sequence variations

\begin{tabular}{lllllllll}
\hline & $\mathbf{n}$ & $\mathbf{T}$ & $\mathbf{C}$ & $\mathbf{A}$ & $\mathbf{G}$ & si & sv & si/sv \\
\hline Total & 599 & 30.7 & 24.3 & 26.8 & 18.2 & 65 & 64 & 1.07 \\
1st & 200 & 20.1 & 23.3 & 25.9 & 30.7 & 17 & 5 & 3.37 \\
2nd & 200 & 42.0 & 27.1 & 13.6 & 17.3 & 1 & 2 & 0.70 \\
3rd & 199 & 30.0 & 22.4 & 41.0 & 6.6 & 47 & 57 & 0.82 \\
\hline
\end{tabular}

Note: n, number of sites; $s i$, transitions; $s v$, transversions

Table 3. Variable sites of amino acid sequences

\begin{tabular}{|c|c|c|c|c|c|c|c|c|c|c|c|c|c|c|c|c|c|c|c|c|c|c|c|c|c|}
\hline & & & & & & & & & & & & & & & & & & & & & 1 & 1 & 1 & 1 & 1 \\
\hline & & & & 1 & 1 & 1 & 1 & 5 & 6 & 6 & 6 & 7 & 7 & 8 & 8 & 8 & 8 & 8 & 9 & 9 & 0 & 0 & 1 & 1 & 1 \\
\hline & 3 & 6 & 7 & 0 & 7 & 8 & 9 & 4 & 0 & 7 & 8 & 5 & 6 & 1 & 4 & 5 & 7 & 8 & 1 & 3 & 4 & 5 & 0 & 2 & 3 \\
\hline C. cyclurus & $\mathrm{S}$ & $\mathrm{L}$ & $\mathrm{L}$ & A & S & $\mathrm{L}$ & $\mathrm{L}$ & $\mathrm{V}$ & A & $\mathrm{R}$ & $\mathrm{L}$ & $\mathrm{L}$ & $\mathrm{L}$ & $\mathrm{T}$ & $\mathrm{L}$ & S & A & A & K & A & $\mathrm{S}$ & S & A & A & S \\
\hline E. alexandri & - & I & . & . & . & . & . & . & . & . & . & . & . & . & V & 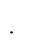 & . & . & $\mathrm{H}$ & V & A & . & S & $\mathrm{P}$ & $\mathrm{P}$ \\
\hline H. japonica & & 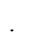 & . & . & . & . & . & . & . & . & . & . & . & . & . & . & . & . & . & V & $\mathrm{A}$ & . & . & $\mathrm{P}$ & 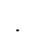 \\
\hline H. atoka & . & . & . & . & . & & . & . & . & . & . & . & . & . & . & . & . & . & . & V & $\mathrm{A}$ & . & . & $\mathrm{P}$ & . \\
\hline M.nanaimoensis & A & I & I & . & . & . & I & . & . & . & . & . & . & S & . & . & $\mathrm{S}$ & $\mathrm{L}$ & . & . & . & . & . & $\mathrm{P}$ & . \\
\hline N.abiuma & & 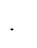 & . & I & A & $\mathrm{F}$ & . & . & . & . & . & . & . & . & . & A & . & . & . & V & A & G & . & $\mathrm{P}$ & . \\
\hline N.elobeyensis & $\mathrm{Y}$ & . & . & I & A & $\mathrm{F}$ & . & . & . & . & . & I & $\mathrm{F}$ & . & I & A & . & $\cdot$ & . & $\mathrm{V}$ & A & G & . & $\mathrm{P}$ & . \\
\hline N.aphroditoides & & ${ }^{\circ}$ & . & . & A & . & . & . & $\mathrm{L}$ & . & M & . & . & . & V & A & . & . & . & $\mathrm{V}$ & A & . & . & $P$ & . \\
\hline$N$. heterocirrata & . & . & . & . & . & . & . & . & . & . & . & . & . & . & . & . & . & . & . & . & . & . & . & . & . \\
\hline N. pelagica & . & . & . & . & . & . & . & . & . & . & . & . & . & . & . & . & . & . & . & . & . & . & . & r & . \\
\hline N. vexillosa & 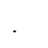 & . & . & . & . & . & . & . & . & . & . & . & . & . & . & . & . & . & . & . & . & . & . & . & . \\
\hline N. virens & & 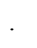 & . & . & . & . & . & . & . & . & . & . & . & . & . & $\cdot$ & . & . & . & . & A & . & . & $\mathrm{P}$ & . \\
\hline N. zonata & . & . & . & . & . & . & . & . & . & . & . & . & . & . & . & . & . & . & . & V & . & . & . & r & . \\
\hline P. aibuhitensis & 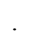 & 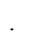 & . & . & . & . & . & . & . & . & . & . & . & . & . & . & . & . & . & $\mathrm{V}$ & A & . & . & $\mathrm{P}$ & . \\
\hline P. falklandica & . & . & . & . & A & . & . & . & . & . & . & . & . & . & . & $\cdot$ & . & . & . & $\mathrm{V}$ & A & . & . & $\mathrm{P}$ & . \\
\hline P. gualpensis & & 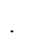 & & . & A & . & . & $\mathrm{L}$ & $\cdot$ & . & . & . & . & I & . & . & . & . & . & $\mathrm{V}$ & $\mathrm{A}$ & . & . & $\mathrm{P}$ & . \\
\hline P. longidonta & & ${ }^{\circ}$ & . & . & A & . & . & . & $\cdot$ & . & . & . & . & . & . & . & . & . & . & V & $\mathrm{A}$ & . & . & $\mathrm{P}$ & . \\
\hline P.singaporiensis & & . & . & . & . & . & . & . & . & . & . & . & . & . & . & $\cdot$ & . & . & . & $\mathrm{V}$ & $\mathrm{A}$ & . & . & $\mathrm{P}$ & . \\
\hline P. vallata & . & $\cdot$ & . & . & . & . & . & . & . & . & . & . & . & . & . & . & . & . & . & $\mathrm{V}$ & A & . & . & $\mathrm{P}$ & . \\
\hline P.bicanaliculata & & . & . & . & . & . & . & . & s. & . & . & . & . & . & . & . & . & . & . & V & . & . & . & $\mathrm{P}$ & . \\
\hline P. dumerilii & & . & . & . & . & . & . & 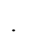 & . & $\mathrm{Q}$ & . & . & . & $\mathrm{S}$ & . & . & . & . & . & $\mathrm{V}$ & . & . & . & $\mathrm{P}$ & . \\
\hline
\end{tabular}




\begin{tabular}{|c|c|c|c|c|c|c|c|c|c|c|c|c|c|c|c|c|c|c|c|c|c|c|c|c|}
\hline & 1 & 1 & 1 & 1 & 1 & 1 & 1 & 1 & 1 & 1 & 1 & 1 & 1 & 1 & 1 & 1 & 1 & 1 & 1 & 1 & 1 & 1 & 1 & 1 \\
\hline & 2 & 2 & 2 & 3 & 3 & 3 & 4 & 4 & 4 & 4 & 4 & 4 & 4 & 5 & 5 & 5 & 5 & 6 & 6 & 6 & 6 & 7 & 7 & 8 \\
\hline & 1 & 6 & 7 & 0 & 3 & 9 & 0 & 1 & 4 & 5 & 7 & 8 & 9 & 2 & 3 & 4 & 8 & 0 & 1 & 3 & 4 & 3 & 4 & 9 \\
\hline C. cyclurus & $\mathrm{L}$ & $\mathrm{V}$ & $\mathrm{S}$ & M & $\mathrm{L}$ & $\mathrm{V}$ & I & $\mathrm{N}$ & $\mathrm{S}$ & K & $\mathrm{L}$ & $\mathrm{R}$ & $\mathrm{L}$ & $\mathrm{V}$ & $\mathrm{S}$ & $\mathrm{L}$ & $\mathrm{S}$ & $\mathrm{V}$ & I & A & $\mathrm{V}$ & $\mathrm{L}$ & A & A \\
\hline E. alexandri & . & . & . & $\mathrm{L}$ & I & . & $\mathrm{L}$ & . & . & $\mathrm{T}$ & M & . & . & . & $\mathrm{P}$ & . & . & $\mathrm{K}$ & . & . & I & . & . & . \\
\hline H. japonica & . & . & . & . & . & . & . & . & . & . & . & . & . & . & $\mathrm{P}$ & . & . & M & . & . & $\mathrm{I}$ & . & . & . \\
\hline H. atoka & . & . & . & . & . & . & . & . & . & . & . & . & . & . & $\mathrm{P}$ & . & . & M & . & . & I & . & . & . \\
\hline M.nanaimoensis & . & . & . & $\mathrm{L}$ & . & I & M & . & $\mathrm{P}$ & $\mathrm{S}$ & . & . & M & . & . & . & . & $\mathrm{L}$ & . & . & I & . & . & . \\
\hline N.abiuma & . & . & . & $\mathrm{L}$ & . & . & M & . & $\mathrm{T}$ & . & . & . & . & . & $\mathrm{P}$ & . & . & M & . & . & I & . & . & . \\
\hline N.elobeyensis & $\mathrm{F}$ & . & $\mathrm{F}$ & $\mathrm{L}$ & . & . & M & $\mathrm{K}$ & $\mathrm{T}$ & . & . & . & . & . & $\mathrm{P}$ & $\mathrm{K}$ & . & M & . & G & I & $\mathrm{V}$ & . & . \\
\hline N.aphroditoides & . & I & . & $\mathrm{L}$ & $\mathrm{V}$ & I & . & . & . & . & $\mathrm{Y}$ & . & . & . & $\mathrm{P}$ & . & A & $\mathrm{K}$ & . & . & I & . & . & $\mathrm{S}$ \\
\hline N. heterocirrata & . & . & . & . & . & . & . & . & . & . & . & . & . & I & $\mathrm{P}$ & . & . & . & . & . & . & . & . & . \\
\hline$N \cdot$ pelagica & . & . & . & . & . & . & . & . & . & . & . & . & . & . & $\mathrm{P}$ & . & . & . & . & . & . & . & . & $\cdot$ \\
\hline$N$. vexillosa & . & . & . & . & . & . & . & . & . & . & . & . & . & . & . & . & . & . & . & . & . & . & . & . \\
\hline N. virens & . & . & . & . & . & . & . & . & . & . & . & . & . & . & $\mathrm{P}$ & . & . & M & . & . & I & . & . & . \\
\hline N. zonata & . & . & . & . & . & . & . & . & . & . & . & . & . & . & $\mathrm{P}$ & . & . & . & . & . & . & . & . & . \\
\hline P. aibuhitensis & . & . & . & . & . & . & . & . & . & . & . & . & . & . & $\mathrm{P}$ & . & . & M & V & . & I & . & . & . \\
\hline P. falklandica & . & . & . & . & . & . & . & . & . & . & . & . & . & I & $\mathrm{P}$ & . & . & . & . & . & I & . & . & . \\
\hline P. gualpensis & . & . & . & $\mathrm{L}$ & . & . & . & . & . & . & . & . & . & . & $\mathrm{P}$ & . & . & M & . & . & I & . & . & . \\
\hline P. longidonta & . & . & . & . & . & . & . & . & . & . & . & . & . & . & $\mathrm{P}$ & . & . & M & V & . & I & . & . & . \\
\hline P.singaporiensis & . & . & . & . & . & . & . & . & . & . & . & . & . & . & $\mathrm{P}$ & . & . & M & $\mathrm{V}$ & . & I & . & . & . \\
\hline P. vallata & . & . & . & . & . & . & . & . & . & . & . & . & . & . & $\mathrm{P}$ & . & . & M & $\mathrm{V}$ & . & I & . & . & . \\
\hline \multicolumn{25}{|l|}{ P.bicanaliculata } \\
\hline P. dumerilii & & & & & & & & & & & & & & & & & & & & & & & & \\
\hline
\end{tabular}

\subsection{Phylogenetic Relationships}

Both constructed NJ tree and ML tree showed two obvious clusters for the 21species (Fig. 4), although the bootstrap value was low and the net genetic distance between the two clades was 0.027 (mean genetic distance was 0.272). Clade A included 10 species from three genera (Hediste, Perinereis and Namalycastis), and clade B contained the left 11 species corresponding to 7 genera including the two outgroup species. The only two species from Namanereidinae subfamily showed monophyletic with a $100 \%$ support. But it was under different status in the two phylogenetic trees and didn't display a relative far distance with other species from Nereidinae. The Perinereis vallata was close to Perinereris aibuhitensis, and they are monophyletic in both two trees. The two Japanese species living in brackish have the closest relationships with high bootstrap value and lay on the end of branch. The two outgroup species from Hesionidae and Syllidae didn't observably diverge from the species of Nereididae, both of them were divided into clade B. Conversely, the Neanthes virens has a closer relation with Nereimyra aphroditoides (Hesionidae, Hesioninae). The four species belong to Nereis clustered together in both NJ and ML trees. But the Cheilonereis cyclurus was also mixed among them. According Table 1 and Fig. 4, the species in clade A were 


\section{Macrothink

mostly distributed coasts of tropic and temperate zone in Pacific, whereas those from clade B were sampled in high latitude areas especially in the coasts of Europe and Northwestern Atlantic.

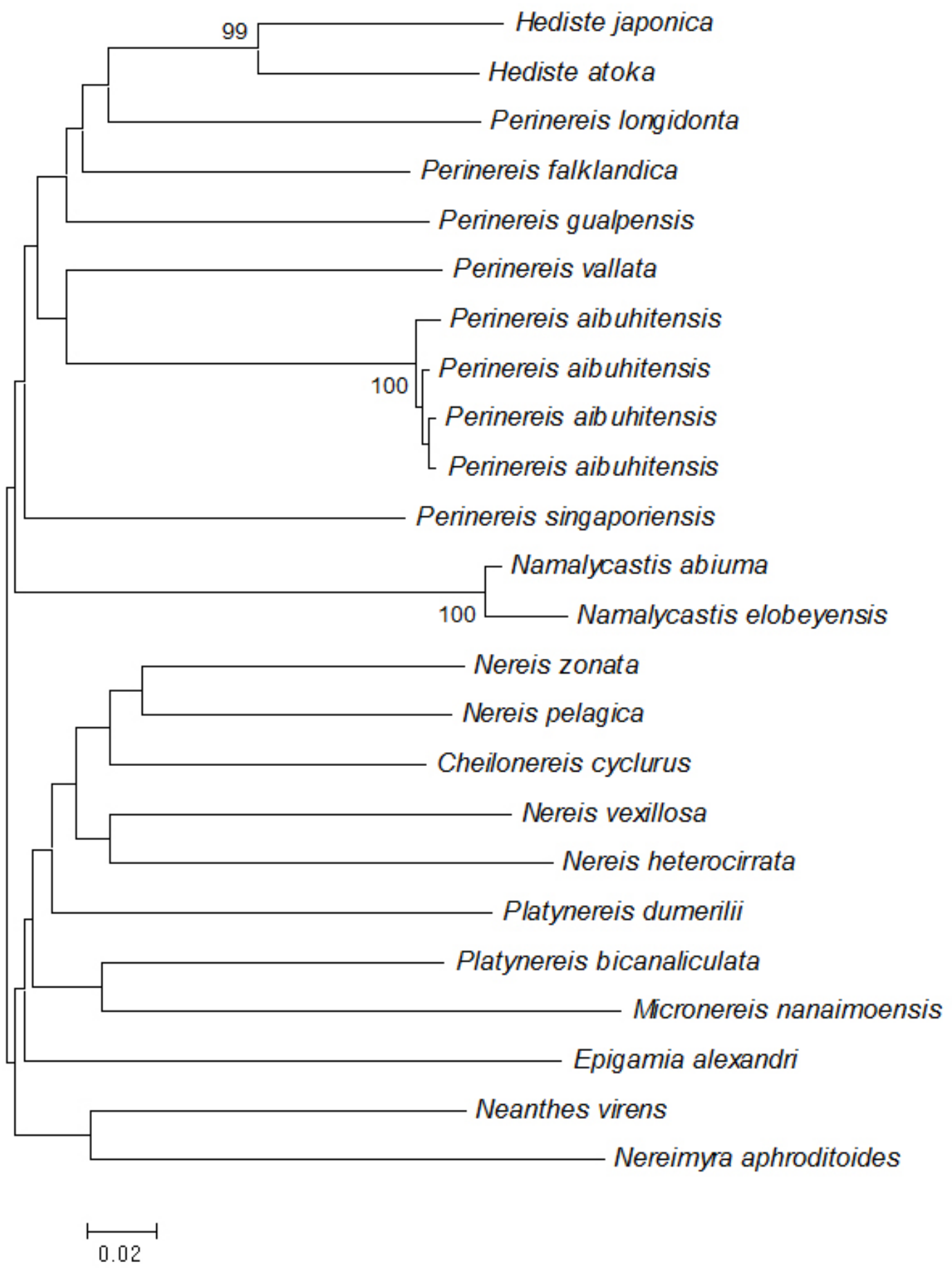

(a) 


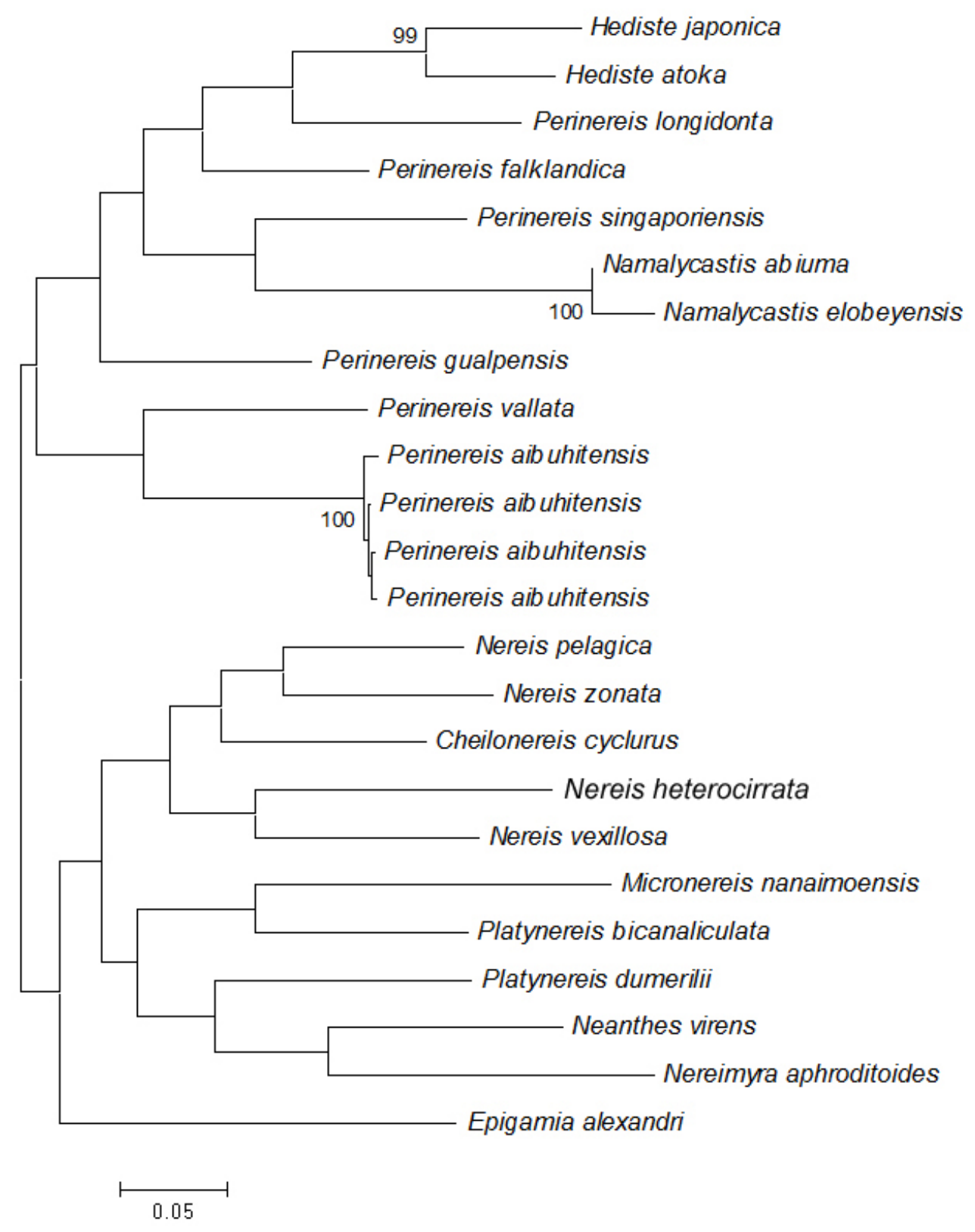

(b)

Figure 4 . The phylogenetic tree of 21 species based on COI sequences. $>90 \%$ bootstrap support was also shown. (a) NJ tree, (b) ML tree

\section{Discussion}

Unlike being conservative in vertebrates, mtDNA COI gene in the nereids species showed high polymorphism. It therefore generated large genetic differentiations between species and supported well several monophyletic groups of currently accepted taxa. Although most clusters in the phylogenetic tree were lack of high bootstrap support and were different with previous results of morphological parsimony analysis (see Santos et al., 2005; Bakken et al., 
20005), it can reflect some clear trends and provide new insights in phylogenetic relationships of Nereididae.

Specially, two shallow clades were revealed among all 21 species analyzed by both NJ and ML tree. For clade A, it consist of the Namalycastis genus in Namanereidinae subfamily and two genera (Hediste and Perinereis) in Nereidinae subfamily. Namanereidinae subfamily was suggest be closest to ancestors by Fitzhugh (1987) based on morphological variations. In present study, the two species Namalycastis abiuma and Namalycastis elobeyensis are obviously monophyletic and display relative longer evolutionary branch length than other species in clade A, indicating the Hediste and Perinereis genera were likely derived from Namanereidinae. Considering that most Namanereidinae species have a tropic distribution whereas Hediste and Perinereis species live in both tropic and temperate areas of northern and southern hemisphere, we postulated that the two genus species might diverge from tropic ancestor northward and southward respectively by transequatorial dispersal events during recent glaciations which have been widely proposed as a mechanism for the formation of antitropical distributions in marine organisms (Lindberg, 1991).

Perinereis vallata clustered with Perinereis aibuhitensis both of which are the common species along coasts of China, but Perinereis vallata has more wide range that can reach as far as coasts of Chile in southern hemisphere. It indicated the divergence between the two species may occur late. Far distance isolation between sampling sites did not have enough time to produce large genetic variations in $\mathrm{COI}$ gene.

Hediste atoka was accepted as a sympatric sibling species with Hediste japonica in recent years (Sato \& Masuda, 1997; Sato et al., 2003). They were distinguished by different egg size (large-egg form or small-egg form) and are reproductively isolated (Sato \& Tsuchiya, 1991). Both the two species live in the brackish-water and have the shortest evolutionary branches indicating they may evolve from marine Perinereis species distributed in Northwestern Pacific.

Clade B mainly contains the Nereis, Platynereis, Cheilonereis, Neanthes, Micronereis and the two outgroup species. All these referred species were mostly distributed in the coasts of Eastern Pacific and Atlantic with middle and high latitude in Northern Hemisphere. Four Nereis species clustered together but a Cheilonereis species get mixed into them. It may indicate the taxon status of this species should be reconsidered and suggest it be divided into Nereis genera. Alternatively, the Nereis genus may be paraphyletic and can be further subdivided. Two Platynereis species (Platynereis bicanaliculata and Platynereis dumerilii) did not form a monophyly suggesting they might belong to different groups.

Micronereis genus was treated as a member of Nereidinae subfamily traditionally. Santos et al. (2005) separated a species Micronereis variegate into Notophycinae based on morphological supports. In our result, another species Micronereis nanaimoensis also showed relative large genetic distances with other species. It supports splitting Micronereis genus into a higher taxonomy status.

The two outgroup species from different families didn't show the farthest distance with all 
the species of Nereididae family. They were also included in clade B. It may be attributed to the high polymorphism of the COI sequences. Especially, the ratio for si/sv is under 1.0 in the second and third coden positions indicating the transitions have reached equilibration (Wu et al., 2007). Such case was often observed in studies of COI sequences for other species and prompted a parallel evolution (Simon et al., 1994). However, there is also report pointing out that substitution saturated won't influence the phylogenetic relationships (Goldstein \& Specht, 1998). High transversions in the third coden positions may be caused by an AT rich (Hugall et al., 1997).

It is interesting that the species in clade B were also be reported to be distributed around coasts of China except Micronereis nanaimoensis, Neanthes virens and the two outgroup species. However almost all of them were sampled around coasts of North America except Nereis heterocirrata, which had the same sampling site with Perinereis aibuhitensis but they belong to different clades. If the hypothesis of two evolutionary origins, the species distributed around coasts of China but from clade B may have a colonization route from north to south which were opposite to Perinereis species. During these processes, the ocean currents likely have a transporting function to accelerate their dispersal, because the eggs and larvae have a planktonic period lasting at least 20 days before they settle into benthos (Sun \& Yang, 2004).

The present study demonstrates the effectiveness of DNA barcoding as a tool for species identification in Nereididae. In consideration of the high polymorphism in this gene, more conservative markers should be used and samples should be collected from more wide geographic areas to verify our hypothesis in future works.

\section{Acknowledgement}

This research was supported by the National Marine Public Welfare Research Project (No. 201005007) and Science and Technology Project of Shandong Provincial Oceanic and Fishery Administrative Department.

\section{References}

Bakken, T., \& Wilson, R. S. (2005). Phylogeny of nereidids (Polychaeta, Nereididae) with paragnaths. Zool. Scr., 34, 507-547. http://dx.doi.org/10.1111/j.1463-6409.2005.00200.x

Boore, J. L., \& Brown, W. M. (2000). Mitochondrial genomes of Galathealinum, Helobdella, and Platynereis: sequence and gene arrangement comparisons indicate that Pogonophora is not a phylum and Annelida and Arthropoda are not sister taxa. Mol. Biol. Evol., 17, 87-106. http://dx.doi.org/10.1093/oxfordjournals.molbev.a026241

Carr, C. M., Hardy, S. M., Brown, T. M., Macdonald, T. A., \& Hebert, P. D. (2011). A tri-oceanic perspective: DNA barcoding reveals geographic structure and cryptic diversity in canadian polychaetes. PLoS ONE, 6, E22232 http://dx.doi.org/10.1371/journal.pone.0022232

Dahlgren, T., Lundberg, J., Pleijel, F., \& Sundberg, P. (2000). Morphological and molecular evidence of the phylogeny of Nereidiform polychaetes (Annelida). J. Zoolog. Syst. Evol. Res., 38, 249-253. http://dx.doi.org/10.1046/j.1439-0469.2000.384150.x 


\section{Macrothink}

Aquatic Science and Technology ISSN 2168-9148 2013, Vol. 1, No. 1

Dean, H. K. (2001). Some Nereididae (Annelida: Polychaeta) from the Pacific Coast of Costa RicaRev. Biol. Trop., 49(Supl), 37-67.

Felsenstein, J. (1981). Evolutionary Trees from DNA Sequences: A Maximum Likelihood Approach. J. Mol. Evol., 17, 368-376. http://dx.doi.org/10.1007/BF01734359

Felsenstein, J. (1985). Confidence limits on phylogenies: an approach using the bootstrap. Evolution, 39, 783-791. http://dx.doi.org/10.2307/2408678

Fitzhugh, K. (1987). Phylogenetic relationships within the Nereididae (Polychaeta): Implications at the subfamily level. Bull. Biol. Soc. Wash., 7, 174-183.

Fong, P. P., \& Garthwaite, R. L. (1994). Allozyme electrophoretic analysis of the Hediste limnicola - H. diversicolor - H. japonica species complex (Polychaeta: Nereididae). Mar. Biol., 118, 463-470. http://dx.doi.org/10.1007/BF00350303

Goldstein, P. Z., \& Specht, C. D. (1998). Pitfalls in phylogenetic analysis of large molecular data sets. In R. DeSalle, B. Shierwater, and B. Streitand (Eds.), Molecular Ecology and Evolution: Approaches and Applications (pp. 253-274). Switzerland: Birkhauser Verlag. http://dx.doi.org/10.1007/978-3-0348-8948-3_14

Hardy, S. M., Carr, C. M., Hardman, M., Steinke, D., Corstorphine, E., \& Mah, C. (2011). Biodiversity and phylogeography of Arctic marine fauna: insights from molecular tools. Mar Biodivers, 41, 195-210. http://dx.doi.org/10.1007/s12526-010-0056-x

Hugall, A., Stanton, J., \& Moritz, C. (1997). Evolution of the A-T rich mitochondrial DNA of the root knot nematode Meloidogyne hapla. Mol. Biol. Evol., 14, 40-48. http://dx.doi.org/10.1093/oxfordjournals.molbev.a025700

Jiang, M. X., \& Liu, M. H. (2008). Research progress of Nereididae. Mar. Sci., 32, 82-86. (In Chinese).

Lindberg, D. R. (1991). Marine biotic interchange between the Northern and Southern Hemispheres. Paleobiology, 17, 308-324.

Nygren, A., Norlinder, E., Panova, M., \& Pleijel, F. (2011). Colour polymorphisms in the polychaete Harmothoe imbricata (Linnaeus, 1967). Mar. Biol. Res., 7, 54-62. http://dx.doi.org/10.1080/17451001003713555

Pleijel, F. (2001). 20. Nereididae Johnston, 1865. In G.W. Rouse and F. Pleijel (Eds.), Polychaetes (pp. 96-98). Oxford, UK: Oxford University Press.

Radulovici, A. E., Archambault, P., \& Dufresne, F. (2010). DNA Barcodes for Marine Biodiversity: Moving Fast Forward? Diversity, 2, 450-472. http://dx.doi.org/10.3390/d2040450

Read, G., \& Fauchald, K. (2012). World Polychaeta database at http://www.marinespecies.org/polychaeta/aphia.php?p=taxdetails\&id=22496 on 2012-08-24.

Saitou, N., \& Nei, M. (1987). The Neighbor-joining Method: A New Method for 
Reconstructing. Mol. Biol. Evol., 4, 406-425.

Santos, C. S. G., Pleijel, F., Lana, P., \& Rouse, G. W. (2005). Phylogenetic relationships within Nereididae (Annelida: Phyllodocida). Invertebr. Syst., 19, 557-576. http://dx.doi.org/10.1071/IS05001

Sato, M., \& Masuda, Y. (1997). Genetic differentiation in two sibling species of the brackish-water polychaete Hediste japonica complex (Nereididae). Mar. Biol., 130, 163-170. http://dx.doi.org/10.1007/s002270050235

Sato, M., \& Nakashima, A. (2003). A review of Asian Hediste species complex (Nereididae, Polychaeta) with descriptions of two new species and a redescription of Hediste japonica (Izuka, 1908). Zool. J. Linn. Soc., London, 137, 403-445.

Sato, M., \& Tsuchiya, M. (1991). Two patterns of early development in nereidid polychaetes keying out to Neanthes japonica (Izuka). Ophelia, 5(Suppl), 371-382.

Sun, R., \& Yang, D. J. (2004). Fauna Sinica, Invertebrate. In Annelida, Polychaeta (II), Nereidida (vol. 33). Beijing, China: Science Press. (in Chinese).

Tamura, K., Peterson, D., Peterson, N., Stecher, G., Nei, M., \& Kumar, S. (2011). MEGA5: molecular evolutionary genetics analysis using maximum Likelihood, evolutionary distance, and maximum parsimony Methods. Mol. Biol. Evol., 28, 2731-2739. http://dx.doi.org/10.1093/molbev/msr121

Tosuji, H., \& Sato, M. (2010). Genetic evidence for parapatric differentiation of two forms of the brackish-water nereidid polychaete Hediste atoka. Plankton Benthos Res., 5(Suppl.), 242-249. http://dx.doi.org/10.3800/pbr.5.242

Westheide, W., \& Schmidt, H. (2003). Cosmopolitan versus cryptic meiofaunal polychaete species: An approach to a molecular taxonomy. Helgol. Mar. Res., 57, 1-6.

Wu, D. X., Zhu, G. P., Chen, N., Su, C. Y., \& Hao, J. S. (2007). Molecular phylogenetic analysis of Limenitinae (Lepidoptera, Nymphalidae) based on mitochondrial COI gene sequences. Lif. Sci. Res., 11, 64-71.

Xia, X. H. (2001). Data Analysis in Molecular Biology and Evolution. Kluwer Academic Publishers.

Zhou, H., Zhang, Z. N., Chen, H. Y., Sun, R. H., Wang, H., Guo, L., \& Pan, H. J. (2010). Integrating a DNA barcoding project with an ecological survey: a case study on temperate intertidal polychaete communities in Qingdao, China. Chin. J. Oceanol. Limnol., 28, 899-910. http://dx.doi.org/10.1007/s00343-010-9131-1

\section{Copyright Disclaimer}

Copyright reserved by the author(s).

This article is an open-access article distributed under the terms and conditions of the Creative Commons Attribution license (http://creativecommons.org/licenses/by/3.0/). 